\title{
Challenging Student Approaches to ESL Vocabulary Development ${ }^{1}$
}

Michael Lessard-Clouston

Vocabulary is a "current word" in second language (L2) pedagogy (Anthony $\mathcal{E}$ Menasche, 1991). In a communicative approach to language teaching, this is helpful due to the importance of meaning both in learning and understanding English as a second language (ESL). However, to date student approaches to vocabulary acquisition have essentially been neglected in the classroom. This article describes an activity that used a questionnaire on student methods of vocabulary learning as a springboard for class discussion of helpful strategies suggested in the literature. After introducing the background for the activity, the procedures and results are outlined. Then suggestions for using a similar questionnaire in other adult ESL contexts are summarized.

\section{Background}

As Maiguashca (1993) notes in an overview on vocabulary learning and instruction, vocabulary used to be the "poor relation" of language teaching, but now it seems to occupy the position of "guest of honor." This recent shift is significant because, as Wilkins (1972) states,

There is not much value in being able to produce grammatical sentences if one has not got the vocabulary that is needed to convey what one wishes to say ... While without grammar very little can be conveyed, without vocabulary nothing can be conveyed. (pp. 110-111)

Wallace (1982) went beyond this point to note that "not being able to find the words you need to express yourself is the most frustrating experience in speaking another language" (p. 9). This quotation is often echoed as I listen to students report that vocabulary appears to be the most difficult aspect of language learning for them to master. In addition to noting that many other people share their feelings, I have begun to place more emphasis on vocabulary learning in my ESL classes.

Despite the recent appearance of many helpful resources for teachers and learners in recent years, ${ }^{2}$ some writers have declared that vocabulary acquisition remains "a neglected aspect of language learning" (Meara, 1980). In a review of various vocabulary learning techniques, for example, Oxford and Crookall (1990) declared that "vocabulary is not explicitly taught in most language classes" (p. 9). More recently, Oxford and Scarcella (1994) added that "students are usually expected to learn vocabulary on their own without 
much guidance" (p. 231). Language learning strategies (Oxford, 1990) are thus crucial, and it is important for ESL instructors to help students understand their own approaches to vocabulary learning.

One recent study, by Sanaoui (1992), considered how L2 students approach the complex task of vocabulary learning. In brief, Sanaoui's initial case studies in ESL revealed two major approaches to vocabulary learning: "structured" and "unstructured." The major difference between the two is that students with a structured approach used systematic, organized methods for learning and reviewing vocabulary acquired both inside and outside of their ESL classes, whereas unstructured learners did not. The structured learners also created self-initiated opportunities to learn and use L2 vocabulary, and spent more time reviewing it. In addition, a further phase of the study with French as a second language (FSL) learners revealed that although a student's level of proficiency and type of instruction did not affect his or her vocabulary learning, the individual approach (structured or unstructured) to vocabulary study did contribute significantly to lexical learning (Sanaoui, 1992).

Sanaoui's (1992) study and results were of interest to me because I often deal with ESL students who go on to study in English at North American universities. Lexical knowledge and learning strategies are especially important to these individuals because, as Casanave (1992) has noted, learning the specialized terminology of their academic disciplines is crucial to their success. As a result, I carried out a small-scale case study in one ESL course I was teaching, using materials I adapted from Sanaoui's (1992) work. Like Sanaoui's study, mine also easily revealed "structured" and "unstructured" groups. However, half of the participants in my class were categorized as "semistructured" learners because they displayed mostly "structured" characteristics but did not meet all of the criteria associated with the structured approach to vocabulary learning. The findings and discussion of that case study are described in more detail elsewhere (Lessard-Clouston, in press). As an ESL instructor, my purpose in the classroom was twofold. First, I wanted to use the materials as a springboard for discussion of vocabulary learning strategies. Second, I endeavored to help my students reflect on their own approaches to vocabulary learning. In the rest of this article I focus on the classroom activity by describing how I used the materials included in the Appendices.

\section{The Classroom Activity}

The Context

The activity was carried out with one intact TOEFL Preparation class which was to introduce students to the Test of English as a Foreign Language (TOEFL). This course was taught at a suburban campus of a college of 
applied arts and technology in Toronto, and aimed (a) to provide a review of all the major points covered in the TOEFL, as well as (b) to introduce them to strategies that might assist in their learning English beyond the course itself. Vocabulary learning is stressed because of its importance throughout the test (Mahnke \& Duffy, 1992, p. 244). Usually only students in the college's top three levels are able to pass a multiple-choice test (with $75 \%$ ) in order to register for this course. Accordingly, only high intermediate and advanced ESL students take it to prepare for the TOEFL. Seventeen adults completed the course. As in many ESL classes, most of these students were women, and they came from a variety of first language backgrounds, including Cantonese, Portugese, Romanian, Polish, Croatian, Japanese, Hebrew, Russian, and Spanish. Their class met two evenings a week for 10 weeks in the winter 1993 term, from January to April.

\section{Procedures and Questionnaires}

Throughout the term, classes centered on the review of major grammar points, vocabulary, and reading and listening comprehension strategies essential to success on the TOEFL. These were taught using hand-outs and various exercises in the course text by King and Stanley (1989). Beyond the text, newspaper articles, video clips and other realia were included in order to use the strategies discussed in the course with materials students would encounter outside of class. Class activities included individual TOEFL practices, pair, and small-group work.

Having read Sanaoui's (1992) study and attended a presentation she gave, I took a more organized approach to the vocabulary aspect of the course, especially because vocabulary represents a very small part of the King and Stanley (1989) text. Near the beginning of the course I gave a mini-lecture summarizing Sanaoui's study and encouraging students to consider a more structured approach to their vocabulary learning. I noted that a good vocabulary is essential to TOEFL success and suggested they use a vocabulary notebook, vocabulary cards, or some other system in order to write down and review the new words and expressions they were learning both in and outside of class.

Each time the basis for a vocabulary learning strategy (VLS) came up in the text or other materials, I wrote it on the blackboard and discussed with the class how individuals might use this VLS to increase their vocabulary knowledge. For example, in a listening exercise, words with multiple definitions are listed, and students choose the answer with the meaning or usage of the word that best reflects its meaning in the sentence they hear on the audiotape. Students in the class then provide examples of other multi-definition words they know, and we discuss how we can increase our vocabulary knowledge by learning new meanings for words we already know. Students are then challenged to keep track of these on vocabulary cards or in a 
vocabulary notebook. Other VLSs discussed include using synonyms, antonyms, word form, word lists, word derivation, word category charts, generality versus specificity, and so forth to build on one's vocabulary knowledge.

During the second class in the seventh week of the course, students were asked to fill out a two-page questionnaire on their individual vocabulary learning habits and strategies. This was a modified and much shortened version of the nine-page questionnaire used by Sanaoui (1992) with FSL learners in British Columbia. The aim was to challenge the students to reflect on what they do in order to learn English words by answering questions about their VLSs. Specifically, students chose from several statements that describe what happens when they learn English vocabulary, with reference to where they learn words, whether they keep written records of them, and if they review the words they have written down. As these practices were encouraged in class, students were able to review some important aspects of vocabulary learning and the VLSs discussed. Overall, this part of the activity took approximately 20 to 30 minutes.

On the questionnaire students were also asked to estimate how much time they spent on self-initiated English and vocabulary learning activities, as opposed to doing homework and class-oriented activities. Because these individuals were immersed in an Anglophone environment and taking the TOEFL preparation course, it was expected that they were learning some English vocabulary either in or outside of class. Thus, at the end of the questionnaire, they were asked to list 10 words that they had learned since the beginning of the TOEFL class, and to note whether they had learned them in class or outside of class. A copy of the questionnaire is reproduced in Appendix A.

Exactly one week later, students were asked to fill out a vocabulary knowledge questionnaire (VKQ), which was also adapted from a longer test used by Sanaoui (1992). This task was generic in that it asked all students to provide the same three types of information for each word listed: the meaning(s) of the word, an example of its use in an appropriate English sentence, and an indication of the part of speech to which the word belongs. Meaning and usage are two minimal aspects of vocabulary knowledge. This was also an individualized task because each student received a copy with the same words he or she had listed on the bottom of the first questionnaire the previous week. A sample page from the VKQ is provided in Appendix B. Some students had listed fewer than 10 words on the first questionnaire, so filling out the VKQ took varying amounts of time for different individuals. Overall it took approximately 20 to 25 minutes of class time.

After the students completed the VKQs in class, I collected them and then immediately handed back the first questionnaires on their individual approaches to vocabulary learning. I did this for two reasons. First, with the 
first questionnaire students were only led to think about their approaches to vocabulary learning. With the $\mathrm{VKQ}$, students were able to see for themselves whether they could provide the information requested for the words they said they had learned. In the end, many students found it harder than they had imagined. Second, then, was the fact that students were ready after filling in the VKQ to receive feedback on and discuss the results of their first questionnaire. The next class, in the following week, I returned the VKQs with written feedback. As we see below, both situations led to some fruitful discussion about vocabulary and vocabulary learning.

\section{Feedback and Results}

In summary, the questionnaire findings revealed that only five students kept good written records of the vocabulary they were learning, with slightly more (eight) indicating that they reviewed such words. Not surprisingly, the most common self-initiated learning activities included watching TV, movies, and so forth in English, speaking with native English speakers, and reading English language magazines, newspapers, and books. Interestingly, the vocabulary students listed was quite individualized, with each student noting different words. Examples of such words follow: murder, energizer, nutrient, delay, convict, keen, jet lag, to get steamed about something, and so forth. On the VKQ, the average score for the class was $63.7 \%$, indicating that many students had learned many of the words they said they had. Overall, the class median score was $70 \%$, suggesting general success among students in their self-stated vocabulary learning. ${ }^{3}$

As this was a class activity, and not a form of evaluation for the course, I provided only qualitative written comments on students' questionnaires. On the first questionnaire, when individuals noted (in answer to question two) that they spent time learning English vocabulary in self-initiated activities outside of class I wrote encouraging comments, such as "Great!" or "That's a lot of time! Wonderful!" When students noted that they spent no time on such activities, I wrote "Perhaps you might want to spend some time studying vocabulary on your own." I wrote similar comments about questions three and seven, concerning the self-initiated learning activities students used and the review of the words they were learning. At the bottom of the second page I wrote summary comments to encourage and challenge each student. For example, one student noted that she spent time on many different activities, but said she never wrote down the words she had learned. I praised the variety of VLSs she used but suggested she might want to consider one that included writing words down so she could review them more easily later.

The purpose here was not to condemn students who did not use a structured approach, but rather to accomplish three important things. First, I wanted to show students that some things that they already do, such as 
reading a newspaper or listening to the radio, can be used to learn vocabulary, or can incorporate VLSs. Second, I wanted to reinforce the strategies that many students were using, such as keeping written records and reviewing words, because Sanaoui's (1992) research suggested that these are helpful in vocabulary learning. Third, I wanted a springboard for class discussion about VLSs. In summarizing the results, I praised the class for the variety of VLSs they noted and encouraged them to continue to discover and use strategies they personally found useful. Some students shared examples of VLSs they used and were encouraged when others echoed how these strategies also worked for them. One student, for example, spoke about how she wrote down new words she heard while watching television. She would verify the English spelling with someone and then review and try to use such new words. As a result of the class discussion, students who did not follow a structured approach were able to see that some of the things they do to learn English can be done in an organized way to learn vocabulary more systematically.

In responding to the VKQ, I simply used check marks when students provided a correct meaning, a good example sentence, or the right part of speech. In questionable cases I used a question mark. Where answers were completely wrong, I provided information on the meaning, an example sentence, and/or the part of speech. Students clearly appreciated this feedback. Unlike the TOEFL's multiple-choice questions, the VKQ asked for students to produce answers, and this allowed both me and them to see some of their strengths and weaknesses. Some students could, for example, provide the correct meaning for a word, but could not provide an example. Students were thus able to see the difference between their receptive and productive knowledge of words. I also wrote encouraging notes for students who did well on the VKQ and suggested that those who did not might want to rethink their VLSs or lack of them. In discussing the VKQ in class, we were briefly able to address the issue of what it means to know a word, beyond meaning and usage. Students were also challenged to examine their approaches to vocabulary learning in light of our class discussion and the feedback they had received on their VKQ. Informal discussions with students after class and at the end of the course revealed the success of this activity when students declared that they were both challenged and encouraged in their ESL vocabulary learning through it.

\section{Suggestions}

Since I first used this class activity, I have gone on to use it with another TOEFL Preparation class with equal success. The questionnaires in the appendices are designed without reference to a particular course and could therefore be used in many adult ESL contexts, though perhaps most profitably with high intermediate or advanced students. They could be used in 
various types of communicative ESL courses, such as a listening and speaking class or a vocabulary learning course, as an activity for individuals or pairs where one simply wants to reveal to students something of their vocabulary learning style, approaches, and vocabulary knowledge. In one case I used only the first questionnaire on student approaches to vocabulary learning. Many students in that group had difficulty listing 10 words they had learned, and by itself this revelation was instructive to those involved. Although the first questionnaire alone is useful for discussion of the points summarized above, it does not explicitly consider other aspects of vocabulary knowledge and the issue of just what it means to "know" a word. These points could nonetheless be addressed in other ways. Depending on the class, one might want to use the questionnaires, or others like them, in group work. Pairs could compare similarities and differences in their approaches to vocabulary learning, for example. Groups of three or four could exchange VKQs for peer marking or to assist one another in completing missing answers concerning a word's meaning, writing an example sentence, or providing the appropriate part of speech.

Two further points and suggestions should be made. First, although Sanaoui's (1992) study revealed that one's structured approach was statistically significant in lexical learning, various individuals have pointed out that time spent on vocabulary development also represents a major factor in vocabulary learning. As a result, I tell my students that both time and strategies will work in tandem in their vocabulary learning. As with other endeavors in life, students are aware that time spent on the task of vocabulary learning, as well as the use of personalized VLSs, can enhance their vocabulary learning. Perhaps the key for teachers is to model both by devoting more time to vocabulary learning in our courses as well as introducing and teaching vocabulary learning strategies.

Second, as noted above, only five students in the first class actually kept good written records of the vocabulary they were learning. One way that ESL instructors can encourage learners to be more active in their vocabulary learning is to require students to keep a vocabulary book with words and phrases they are learning, examples of their use, helpful grammatical information, and so forth. Such a notebook could periodically be handed in to the teacher for review and/or feedback. In a subsequent course, I handed out a list with examples of the VLSs we had discussed in class. Then I gave students a take-home assignment to choose two such strategies they had used and write up the VKQ information for five words they had learned using each of the two strategies. I then marked and handed back the assignments. This type of feedback reminds learners both of the course content and their own VLSs. It also encourages students to be more deliberate in their learning and review of vocabulary. 


\section{Conclusion}

Although vocabulary learning and teaching are now receiving more attention in ESL and L2 classes, student approaches to vocabulary acquisition are still greatly neglected. This article outlines a classroom activity that uses materials adapted from Sanaoui's (1992) study to allow students to consider their individual approaches to vocabulary learning and reflect on their vocabulary knowledge. Using the questionnaires included here, or others like them, can serve as a springboard for fruitful discussion of vocabulary knowledge and useful approaches to vocabulary learning. With the suggestions offered here, it is hoped that the questionnaires may be used in other adult ESL contexts to challenge students and their approaches to ESL vocabulary development.

Notes

${ }^{1}$ This article is a revised version of a paper presented at the annual TESL Ontario Conference in Toronto, November 1993. I am grateful to Wendy Lessard-Clouston and the TCJ's editors and reviewers for insightful comments on an earlier version of this article. I also acknowledge and appreciate the participation of the students involved in this course and thank them for their input on this activity and their vocabulary learning.

${ }^{2}$ Although not an exhaustive list, some quite helpful resources for teachers include those by Allen (1983), Carter (1987), Carter and McCarthy (1988), Gairns and Redman (1986), Jackson (1988), Lewis (1993), McCarthy (1990), Morgan and Rivoluari (1986), Nation (1990, 1994), Nattinger and DeCarrico (1992), Taylor (1990,1992), and Willis (1990). Among those oriented toward students are: Harrison (1990), Lougheed (1993), Redman and Ellis (1989, 1990), Seal (1987), Sim and Laufer-Dvorkin (1984), and Wellman (1992).

${ }^{3}$ For further discussion of the case study research questions, procedures, and results, the reader is referred to Lessard-Clouston (in press).

\section{The Author}

Michael Lessard-Clouston is a doctoral candidate in the Modern Language Centre at the Ontario Institute for Studies in Education. He has taught ESL and EFL extensively in China and Canada. His research interests include L2 writing, ESL vocabulary studies, and culture learning. He is part-time ESL faculty at Seneca College, in North York.

\section{References}

Allen, V. (1983). Techniques in teaching vocabulary. Oxford: Oxford University Press.

Anthony, E., \& Menasche, L. (1991). Teaching vocabulary: The current word. In J.E. Alatis (Ed.), Georgetown university round table on languages and linguistics 1991 (pp. 100-113). Washington, D.C.: Georgetown University Press.

Carter, R. (1987). Vocabulary: Applied linguistic perspectives. London: Allen and Unwin.

Carter, R., \& McCarthy, M. (Eds.). (1988). Vocabulary and language teaching. London: Longman.

Casanave, C. (1992). Cultural diversity and socialization: A case study of a Hispanic woman in a doctoral program in sociology. In D. Murray (Ed.), Diversity as resource: Redefining cultural literacy (pp. 148-180). Alexandria, VA: TESOL.

Gairns, R., \& Redman, S. (1986). Working with words. Cambridge: Cambridge University Press. Harrison, M. (1990). Word perfect. Surrey, UK: Nelson.

Jackson, H. (1988). Words and their meaning. London: Longman. 
King, C., \& Stanley, N. (1989). Building skills for the TOEFL (2nd ed.). Surrey, UK: Nelson.

Lessard-Clouston, M. (in press). ESL Vocabulary learning in a TOEFL preparation class: A case study. In B. Harley (Ed.), Research on second language vocabulary learning. Toronto: University of Toronto Press.

Lewis, M. (1993). The lexical approach: The state of ELT and a way forward. Hove, UK: Language Teaching Publications:

Lougheed, L. (1993). Words, more words, and ways to use them. Reading, MA: Addison-Wesley.

McCarthy, M. (1990). Vocabulary. Oxford: Oxford University Press.

Mahnke, K., \& Duffy, C. (1992). The Heinemann TOEFL preparation course. Oxford: Heinemann.

Maiguashca, R. (1993). Teaching and learning vocabulary in a second language: Past, present, and future directions. Canadian Modern Language Review, 50, 83-100.

Meara, P. (1980). Vocabulary acquisition: A neglected aspect of language learning. Language Teaching and Linguistics Abstracts, 13, 221-245.

Morgan, J., \& Rivoluari, M. (1986). Vocabulary. Oxford: Oxford University Press.

Nation, I.S.P. (1990). Teaching and learning vocabulary. New York: Newbury House.

Nation, P. (Ed.). (1994). New ways in teaching vocabulary. Alexandria, VA: TESOL.

Nattinger, J., \& DeCarrico, J. (1992). Lexical phrases and language teaching. Oxford: Oxford University Press.

Oxford, R. (1990). Language learning strategies: What every teacher should know. New York: Newbury House.

Oxford, R., \& Crookall, D. (1990). Vocabulary learning: A critical analysis of techniques. TESL Canada Journal, 7(2), 9-30.

Oxford, R., \& Scarcella, R. (1994). Second language vocabulary learning among adults: State of the art in vocabulary instruction. System, 22(2), 231-243.

Redman, S., \& Ellis, R. (1989). A way with words, Book 1. Cambridge: Cambridge University Press.

Redman, S., \& Ellis, R. (1990). A way with words, Book 2. Cambridge: Cambridge University Press.

Sanaoui, R. (1992). Vocabulary learning and teaching in French as a second language classrooms. Unpublished doctoral dissertation. Toronto: University of Toronto, OISE.

Seal, B. (1987). Vocabulary builder. London: Longman.

Sim, D., \& Laufer-Dvorkin, B. (1984). Vocabulary development. London: Collins.

Taylor, L. (1990). Teaching and learning vocabulary. London: Prentice-Hall.

Taylor, L. (1992). Vocabulary in action. London: Prentice Hall.

Wallace, M. (1982). Teaching vocabulary. London: Heinemann.

Wellman, G. (1992). Wordbuilder. Oxford: Heinemann.

Wilkins, D. (1972). Linguistics in language teaching. London: Arnold.

Willis, D. (1990). The lexical syllabus. London: Collins.

\section{Appendix A}

\section{Questionnaire on Your Approach to Learning Vocabulary}

1. Please check one of the statements below that best describes what happens when you learn English vocabulary:

I learn vocabulary most from activities in English classes, and from the homework assigned for class.

I learn vocabulary from activities in English classes, from homework assigned in my courses, and from self-initiated learning activities I do outside class time. 
2. How much time do you spend each week, on average, learning English vocabulary in activities you initiate out of class?
No time
One hour or less
2-3 hours
4-5 hours
6-10 hours
More than 10 hours

3. Please check off all the self-initiated learning activities listed below that you sometimes use outside of class. Beside each, write the average time you spend on each one per week.

TIME:

I listen to English programmes on the radio

I watch TV programs, movies, etc. in English

I have conversations in English with native speakers

I talk to myself in English (mentally or out loud)

I write letters to people in English

I read books in English regularly

I read a newspaper in English regularly

I read English magazines regularly

I follow English directions in order to perform various tasks (reading recipes, following instructions)

I play games in English (including computer games)

I look up English words I encounter during the week in my bilingual or English-English dictionary

I play English vocabulary games in my mind (using themes, topics, word categories, making lists, etc.)

I use English word puzzles to improve my vocabulary

I practice English vocabulary I have just learned

I engage in other activities I will list below:

4. Which statement below best describes what you do? Choose one:

I keep good written records of the English words I am learning in

class and/or outside of class (i.e. in a vocabulary book, on cards, etc.).

I keep minimal written records but make a mental note of the English words I learn in and /or outside of class.

5. Which statement below best describes what you do? Choose one:

My main reason for writing down English words I am learning is to come back and review them later.

My main reason for writing down English words I am learning is to help me memorize that word.

6. When you write down English words you are learning in class or independently, where do you write them?

7. How often do you review the English words you write down? Check one:

never/rarely

sometimes

often 
8. How do you usually review the English words you write down?

9. Which statement best describes what you do? Check one:

My opportunities for practising the English words I am learning come mostly from class activities and from homework assigned in English courses.

My opportunities for practising the English words I am learning come from activities in class, homework assigned in English courses, and from self-initiated activities I engage in out of class during the week.

10. List ten words below that you have learned in or out of class since this course began (i.e., you didn't know them before) Did you learn them in or out of class?

1.

2.

3.

4.

5.

6.

7.

8.

9.

10.

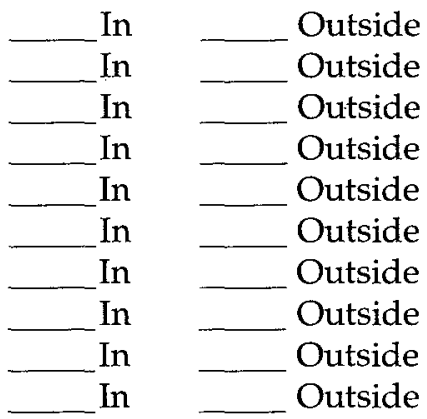

(Adapted from Sanaoui, 1992, pp. 167-175)

\section{Appendix B}

\section{Questionnaire on Your Vocabulary Knowledge}

VOCABULARY WORD \#1:

1. Please explain the meaning or meanings (if more than one) for the above word:

2. Please use this word in a complete sentence in English in order to demonstrate that you know how to use it correctly in an appropriate context.

3. Please indicate what part of speech this word is below. If the word can be more than one part of speech, please indicate all possible parts of speech that you are aware of. a noun IF YES, please indicate the plural below: 
a verb IF YES, please indicate the past tense below:

an adjective IF YES, please indicate the adverb form:

an adverb IF YES, please indicate the adjective form:

something other than a noun, a verb, an adjective, or an adverb.

IF YES, please explain any grammatical characteristics of this word that you know below:

(Adapted from Sanaoui, 1992, pp. 184-185) 